\title{
Residual Herbicide Study on Selected Hanford Site Roadsides
}

Prepared for the U.S. Department of Energy Office of Environmental Restoration and Waste Management

\section{(vi) Westinghouse Hanford Company Richland, Washington}

Hanford Operations and Engineering Contractor for the

U.S. Department of Energy under Contract DE-AC06-87RL10930 
LEGAL DISCLAIMER

This report was prepared as an account of work sponsored by an agency of the United States Government. Neither the United States Government nor any agency thereof, nor any of their employees, nor any of their contractors, subcontractors or their employees, makes any warranty, express or implied, or assumes any legal liability or responsibility for the accuracy, completeness, or any third party's use or the results of such us $\theta$ of any information, apparatus, product, or process disclosed, or represents that its use would not infringe privately owned rights. Reference herein to any specific commercial product, process, or service by trade name, trademark, manufacturer, or otherwise, does not necessarily constitute or imply its endorsement, recommendation, or favoring by the United States Government or any agency thereof or its contraclors or subcontractors. The views and opinions of authors expressed herein do nol necessarily state or reflect those of the United States Government or any agency thereof.

This report has been reproduced from the best available copy. Available in paper copy and microfiche.

Available to the U.S. Department of Energy

and its contractors from

Office of Scientific and Technical Iniormation

P. O. Box 62

Oak Ridg $\theta$, TN 37831

(615) 576.8401

Available to the public from the U.S. Department of Commerce National Technical Information Service

5285 Port Royal Road

Springfield. VA 22161

(703) 487.4650

Prinled in the United Stales ol America

DISCLM-1.CHP (1.91) 


\title{
Residual Herbicide Study on Selected Hanford Site Roadsides
}

\author{
J. L. Smith \\ C. J. Kemp \\ M. R. Sackschewsky \\ Date Published \\ August 1993
}

Prepared for the U.S. Department of Energy Office of Environmental Restoration and Waste Management

\footnotetext{
(W) Westinghouse

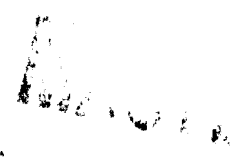




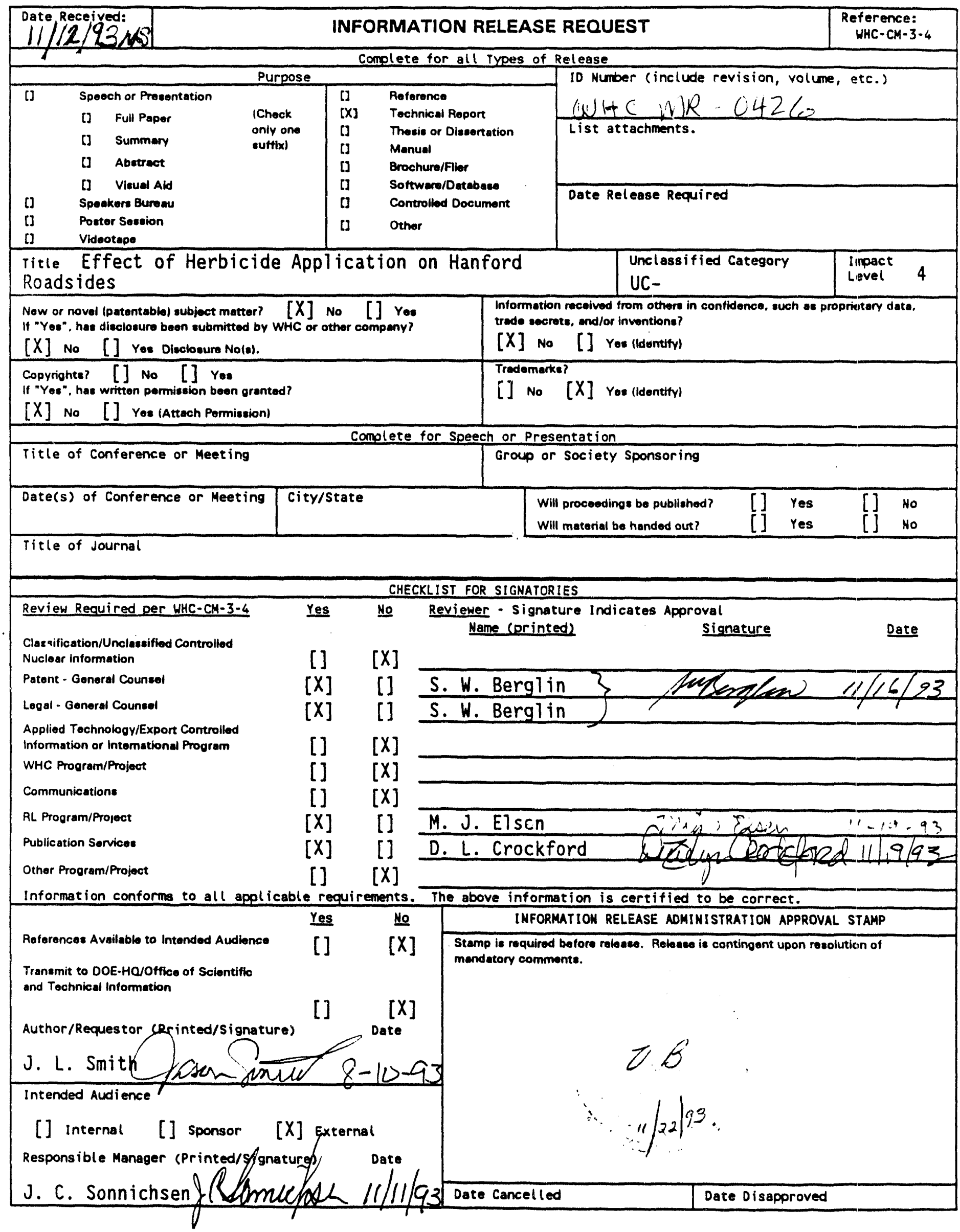


WHC-MR-0420

\section{EXECUTIVE SUMMARY}

Westinghouse Hanford Company routinely treats roadsides with herbicides to control undesirable plant growth. An experiment was conducted to test perennial grass germination in soils adjacent to roadways of the Hanford Site. The primary variable was the distance from the roadside. A simple germination test was executed in a controlled-environment chamber to determine the residual effects of these applications. As expected, the greatest herbicide activity was found directly adjacent to the roadway, approximately 0 to $20 \mathrm{ft}$ $(0$ to $6.3 \mathrm{~m}$ ) from the roadway. 
WHC-MR-0426

\section{CONTENTS}

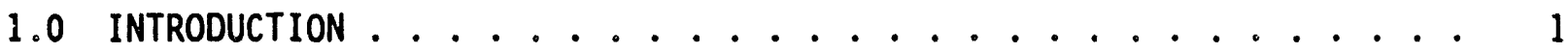

2.0 METHODS AND MATERIALS 2.1 DESCRIPTION OF EXPERIMENTS $\ldots \ldots \ldots \ldots \ldots \ldots$

3.0 RESULTS ............................ 4

4.0 SUMMARY AND CONCLUSIONS ................. 11

5.0 REFERENCES ...................... 11 
WHC-MR-0426

\section{LIST OF FIGURES}

1 Zone "E"-Effect of Depth (Average Plant Height) . . . . . . . . . 5

2 Zone "E"-Effect of Depth (Average Plant Vitality) . . . . . . . . . 6

3 Site and Zone Effects (Average Plant Vitality) ............ 7

4 Site and Zone Effects (Average Plant Height) . . . . . . . . . . 8

5 Site and Zone Effects (Number of Seeds Germinated) . . . . . . . . 9

6 Zone "E"-Effect of Depth (Germination Rate) . . . . . . . . . . 10

\section{LIST OF TABLES}

1 Sample Locations (Trials 1-3) . . . . . . . . . . . . . 2

2 Sample Locations (Trial 4) . . . . . . . . . . . . . 3 
WHC-MR-0420

\section{Residual Herbicide Study on Selected Hanford Site Roadsides}

\subsection{INTRODUCTION}

The Westinghouse Hanford Company (Westinghouse Hanford) performs herbicide applications on the Hanford Site roads for the U.S. Department of Energy. In fiscal year (FY) $1993,160.3 \mathrm{mi}(258.1 \mathrm{~km})$ of designated primary roadway and $110 \mathrm{mi}(177.1 \mathrm{~km})$ of secondary that were treated. Krovar I DF, Direx $4 L$, Weedmaster, a 2-4D product are used to control many annual and perennial grasses and herbaceous weeds. The half-lives of these products are as follows:

- Direx $4 L^{1}$ (Diuron), 6 to 8 months (Montgomery 1993)

- Krovar I DF 7 months (Hartly and Kidd 1987)

- Weedmaster ${ }^{3}$ (2-4D), 6 weeks (Hartly and Kidd 1987)

- $\quad$ Oust $^{4}, 24$ weeks (Montgomery 1993).

Direx $4 L$ was used in the most recent application (FY 1993) and is the primary control agent. The purpose of the experiment was to study the residual herbicide on selected Hanford Site roadsides.

\subsection{METHODS AND MATERIALS}

Soil samples were collected at the beginning of the experiment from Route 2 South (a secondary road) and Route 4 South (a primary roadway). Eight zones were established $(A-H)$, from which samples were taken for each of three trials $(1-3)$. Four replications of each sample for each zone and trial were taken, for a total of 96 samples. Trial 4 was set up for a detailed sampling to determine the location of the herbicide in the soil strata, using a total of 24 samples (4 in each subzone of Zone E). Sample locations are described in Table 1. The soil samples were collected using a shovel at a depth of 2 to $8 \mathrm{in}$. $(5.1$ to $20.3 \mathrm{~cm})$. The soil was characterized as primarily sand and rocks ranging from $1 / 2$ in. $(1.3 \mathrm{~cm})$ to $5 \mathrm{in} .(12 \mathrm{~cm})$ in diameter. The soil was sifted with a $1 / 2-i n .(1.3 \mathrm{~cm})$ soil sieve to remove large rocks that might interfere with seed germination and growth. The samples were placed in 3-in.-square-by-4-in. (7.6-cm-square-by-10.2-cm) deep plastic pots. The pots' drain holes were taped to prevent sample loss. Each sample in each trial was replicated four times.

\footnotetext{
${ }^{1}$ Direx $4 \mathrm{~L}$ is a tradename of Diuron.

${ }^{2}$ Krovar I DF is a tradename of a mixture of Bromacil and Diruon.

3 Weedmaster is a tradename of 2-40.

${ }^{4}$ Oust is a tradename of Sulfomenturon-Methyl.
} 
Table 1. Sample Locations (Trials 1-3).

\begin{tabular}{|c|c|}
\hline $\begin{array}{c}\text { Sample } \\
\text { description }\end{array}$ & Location \\
\hline Sample A & $\begin{array}{l}\text { Route } 2 \text { South, mile } 5.75,0 \text { to } 9 \mathrm{ft} \\
(2.7 \mathrm{~m}) \text { from roadway }\end{array}$ \\
\hline Sample B & $\begin{array}{l}\text { Route } 2 \text { South, mile } 5.75,9 \text { to } 15 \mathrm{ft} \\
(4.6 \mathrm{~m}) \text { from roadway }\end{array}$ \\
\hline Sample C & $\begin{array}{l}\text { Route } 2 \text { South, mile } 5.75,15 \text { to } 20 \mathrm{ft} \\
(6.1 \mathrm{~m}) \text { from roadway }\end{array}$ \\
\hline Sample D & $\begin{array}{l}\text { Route } 2 \text { South, mile } 5.75,100+\mathrm{ft} \\
(30.5 \mathrm{~m}) \text { from roadway }\end{array}$ \\
\hline Sample E & $\begin{array}{l}\text { Route } 4 \text { South, mile } 9.40,0 \text { to } 15 \mathrm{ft} \\
(4.6 \mathrm{~m}) \text { from roadway }\end{array}$ \\
\hline Sample F & $\begin{array}{l}\text { Route } 4 \text { South, mile } 9.40,15 \text { to } 25 \mathrm{ft} \\
(7.6 \mathrm{~m}) \text { from roadway }\end{array}$ \\
\hline Sample $G$ & $\begin{array}{l}\text { Route } 4 \text { South, mile } 9.40,25 \text { to } 30 \mathrm{ft} \\
(9.2 \mathrm{~m}) \text { from roadway }\end{array}$ \\
\hline Sample H & $\begin{array}{l}\text { Route } 4 \text { South, mile } 9.40,100+\mathrm{ft} \\
(30.5 \mathrm{~m}) \text { from roadway }\end{array}$ \\
\hline
\end{tabular}

\subsection{DESCRIPTION OF EXPERIMENTS}

Approximately 150 siberian wheatgrass seeds were deposited per pot in premoistened soil and raked to a depth of $1 / 4$ to $1 / 2$ in. $(0.65$ to $1.3 \mathrm{~cm})$. The soil was then pressed firmly to ensure good seed-to-soil contact. Current recommended seeding rates at the Hanford Site are $151 \mathrm{~b}(33.1 \mathrm{~kg})$ pure live-seed wheatgrass mix per acre in the field. This rate is equivalent to 5.3 seeds per plastic pot. The experimenters overseeded by a factor of almost 30 to ensure that a high number of live seed would be present in the soil samples.

After the seeds were planted in the premoistened soil, water was applied at an average rate of $1.01 \mathrm{oz}(30 \mathrm{ml})$ day, or as needed (e.g., after weekends). Moisture was maintained so that consistent germinations would result. All trials received the same amounts of irrigation at any given time. Each trial lasted between 6 and 10 days, and photographs were taken before disposing of each plot. In viable soil, the heights of the plants were 2.36 to $3.15 \mathrm{in}$. $(6$ to $8 \mathrm{~cm})$.

The samples were housed in a chamber where conditions were controlled within certain criteria (i.e., the observed average temperature was between 29 and $32{ }^{\circ} \mathrm{C}$ and observed humidity was consistently between 25 and 35 percent). An exhaust fan provided good air circulation and ran concurrently with the lighting system. The lighting consisted of three $4-\mathrm{ft}(1.2-\mathrm{m})$ soft-white florescent tubes of 60 watts; there also was one incandescent bulb of 
100 watts. The lighting was provided on a cycle of 14 hours 1 ight and 10 hours dark for any 24-hour period. An automatic timer was set on real time and provided light between 6:00 a.m. and 8:00 p.m. (to minimize any effects from lighting in the building during the day).

In Trials 1 and 2, fertilizer $\left(\left[\mathrm{NH}_{4}\right]_{2} \mathrm{SO}_{4}[21 \times 0 \times 0]\right)$ was applied at the equivalent rate of $20 \mathrm{ib}(9.1 \mathrm{~kg})$ of nitrogen per acre. Fertilizer was not applied to Trials 3 and 4 so that a comparison of the germination times could be made. Fertilizer had no significant effect on the germination rates or time. The first germinations appeared on days 4 and 5 for all trials. At the end of each trial, random counts were made to determine the number of

germinations that occurred in the plots. Approximately 70 to 80 percent of the seeds in viable soil germinated.

Based on the results of the first three trials, Zone $E$ showed the most residual herbicide activity. Trial 4 was a detailed sampling attempting to determine the location of the herbicide(s) in the soll strata. Therefore, additional samples were collected from the original Route 4 South site. An intact core sample would have been ideal but, because of the large rocks present and the lack of necessary equipment, another method was used. Using a shovel and yardstick, each layer of soil was carefully scraped and collected. The following data are for Trial 4 only (also refer to Table 2):

- Sample $E-1=0$ to 2 in. $(5.1 \mathrm{~cm})$ belowgrade

- Sample $E-2=2$ to 4 in. $(10.2 \mathrm{~cm})$ belowgrade

- Sample E-3 = 4 to 6 in. $(14.4 \mathrm{~cm})$ belowgrade

- Sample E-4 $=6$ to 8 in. $(20.3 \mathrm{~cm})$ belowgrade

- Sample E-5 $=8$ to 10 in. $(25.4 \mathrm{~cm})$ belowgrade

- Sample E-6 = 10 to 12 in. $(30.5 \mathrm{~cm})$ belowgrade.

Table 2. Sample Locations (Trial 4).

\begin{tabular}{|l|l|}
\hline \multicolumn{1}{|c|}{$\begin{array}{c}\text { Sample } \\
\text { description }\end{array}$} & \multicolumn{1}{|c|}{ Location } \\
\hline Sample E-1 & $\begin{array}{l}\text { Route } 4 \text { South, mile 9.40, 0 to } 2 \mathrm{in} . \\
(5.1 \mathrm{~cm}) \text { belowgrade }\end{array}$ \\
\hline Sample E-2 & $\begin{array}{l}\text { Route } 4 \text { South, mile 9.40, } 2 \text { to } 4 \mathrm{in} . \\
(10.2 \mathrm{~cm}) \text { belowgrade }\end{array}$ \\
\hline Sample E-3 & $\begin{array}{l}\text { Route } 4 \text { South, mile 9.40, } 4 \text { to } 6 \mathrm{in} . \\
(15.2 \mathrm{~cm}) \text { belowgrade }\end{array}$ \\
\hline Sample E-4 & $\begin{array}{l}\text { Route } 4 \text { South, mile 9.40,6 to } 8 \mathrm{in} . \\
(20.3 \mathrm{~cm}) \text { belowgrade }\end{array}$ \\
\hline Sample E-5 & $\begin{array}{l}\text { Route } 4 \text { South, mile 9.40,8 to } 10 \mathrm{in} . \\
(25.4 \mathrm{~cm}) \text { belowgrade }\end{array}$ \\
\hline Sample E-6 & $\begin{array}{l}\text { Route } 4 \text { South, mile 9.40, } 10 \text { to } 12 \mathrm{in} . \\
(30.5 \mathrm{~cm}) \text { belowgrade }\end{array}$ \\
\hline
\end{tabular}


An intact core sample was collected at a depth of 12 to $18 \mathrm{in.}$ ( 30.5 to $43.2 \mathrm{~cm}$ ), using a coffee can that was driven into the sand under the road base, and the excavation took place at that depth. The can was separated in half, and siberian wheatgrass was planted following the same procedure as previously used. Trial 4 was conducted in the same manner as the first three trials.

\subsection{RESULTS}

Herbicide was applied on the Route 2 South roadside on April 23, 1993. This was the first such application in more than 24 months on the Route 2 South roadside. This suggests that any observable herbicide activity can be attributed to the April 23 application. Route 4 South has received more frequent treatment, in comparison to Route 2 South, for undesirable plant growth in the last several years. The effects of herbicide on Route 4 South is a result of a rigorous weed control program.

At the Route 2 South sample site, the April 23 herbicide application was very effective, al though under ideal conditions provided in the experiment wheatgrass ge-minated. As expected, the greater the distance from Route 2 South roadside there was a slightly greater rate of germination and vigor of the seedlings. A control sample was taken at $100 \mathrm{ft}(30.5 \mathrm{~m})$ from the roadside and presumably had no herbicide activity; all other samples from the Route 2 South site were compared to this control sample.

The Route 4 South sample site also exhibited a lack of plant growth, similar to the Route 2 South roadside. The distance from the roadside at the Route 4 South site correlated to the rates of germination and growth. The lowest germination rates occurred in the sample less than $20 \mathrm{ft}(6.1 \mathrm{~m})$ from the roadside, and the highest germination rates occurred in the control sample $100 \mathrm{ft}(30.5 \mathrm{~m})$ from the road surface.

Trial 4 was a detailed sampling of the site and zone that exhibited the greatest residual herbicide activity. Site 2 of Zone $E$ had the lowest germinations of all plots. This pattern was perpetuated in the samples that came from depths less than 6 in. $(15.2 \mathrm{~cm})$. These samples showed little or no germination. Samples from the 6-to-10-in. (15.2-to-25.4-cm) ranges showed slightly higher germination rates, and the samples from plots greater than 12 in. $(30.5 \mathrm{~cm})$ showed the highest rates from Trial 4 . The intact core showed uniform germination rates and growth rates.

The Figures 1 through 6 are a statistical analysis of the collected data. 
WHC-MR-0426

Figure 1. Zone "E"-Effect of Depth (Average Plant Height).

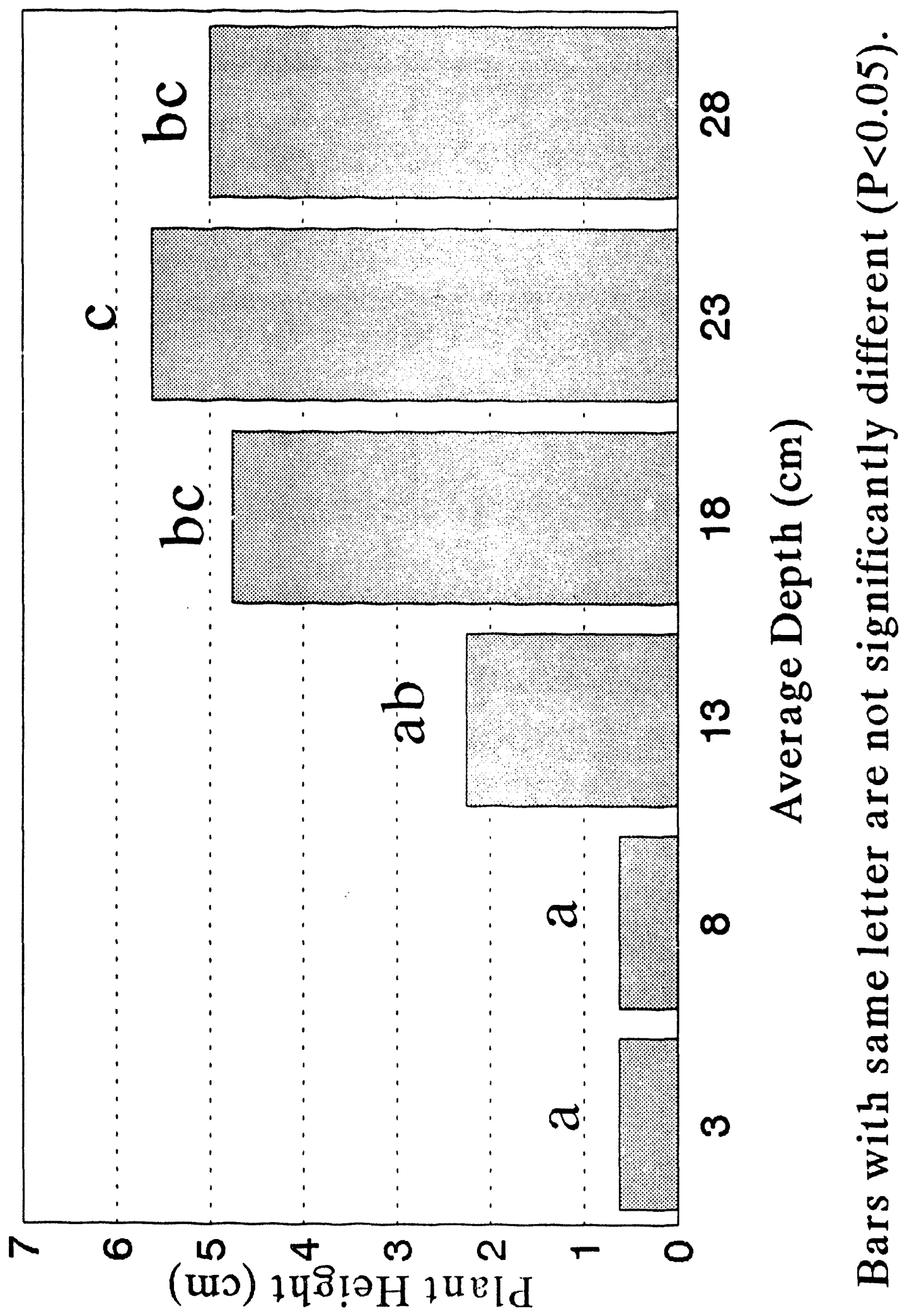




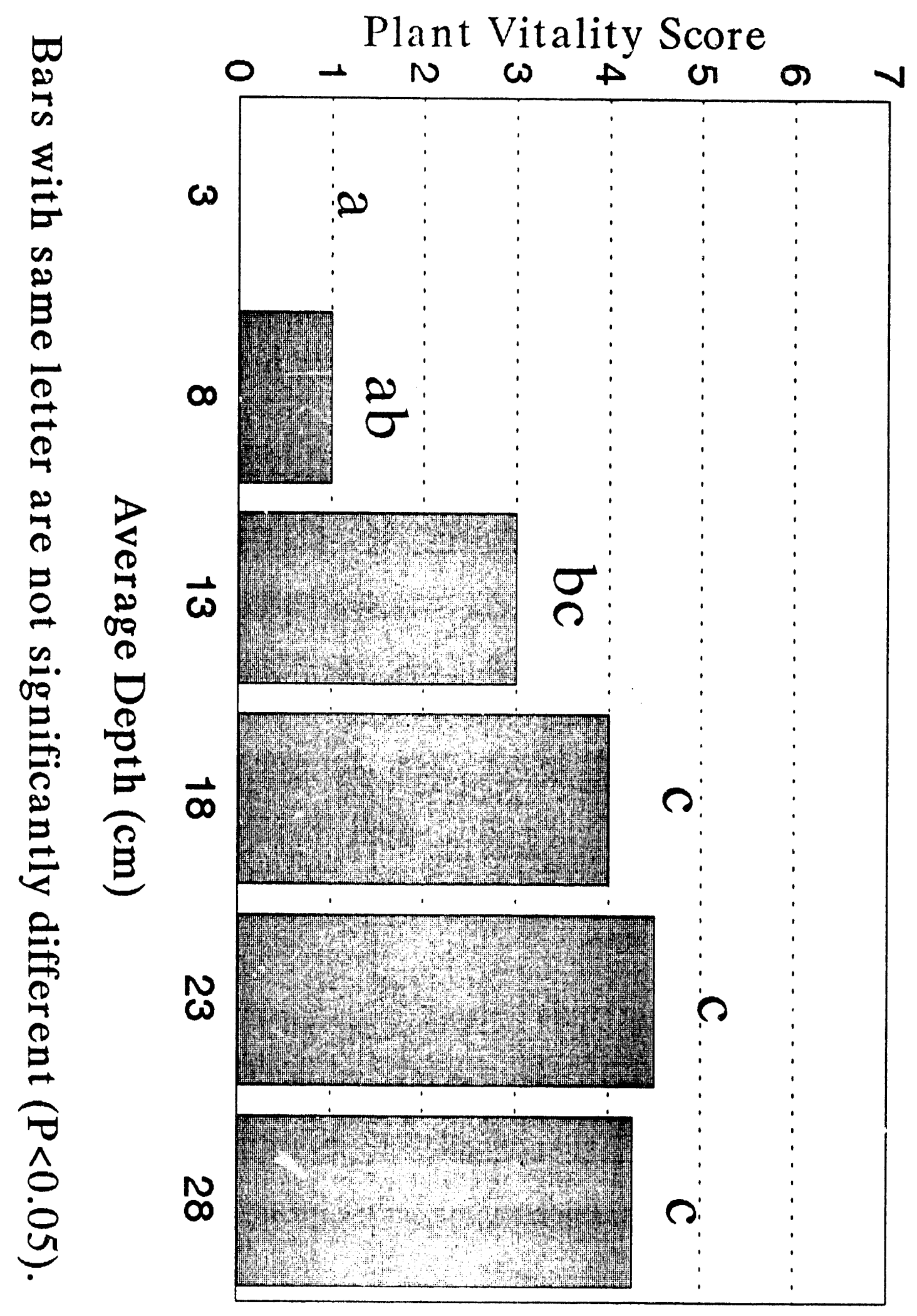

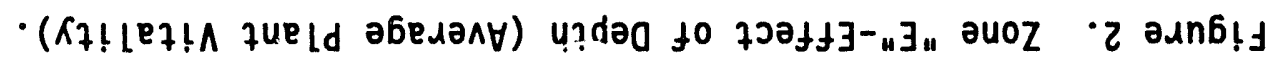




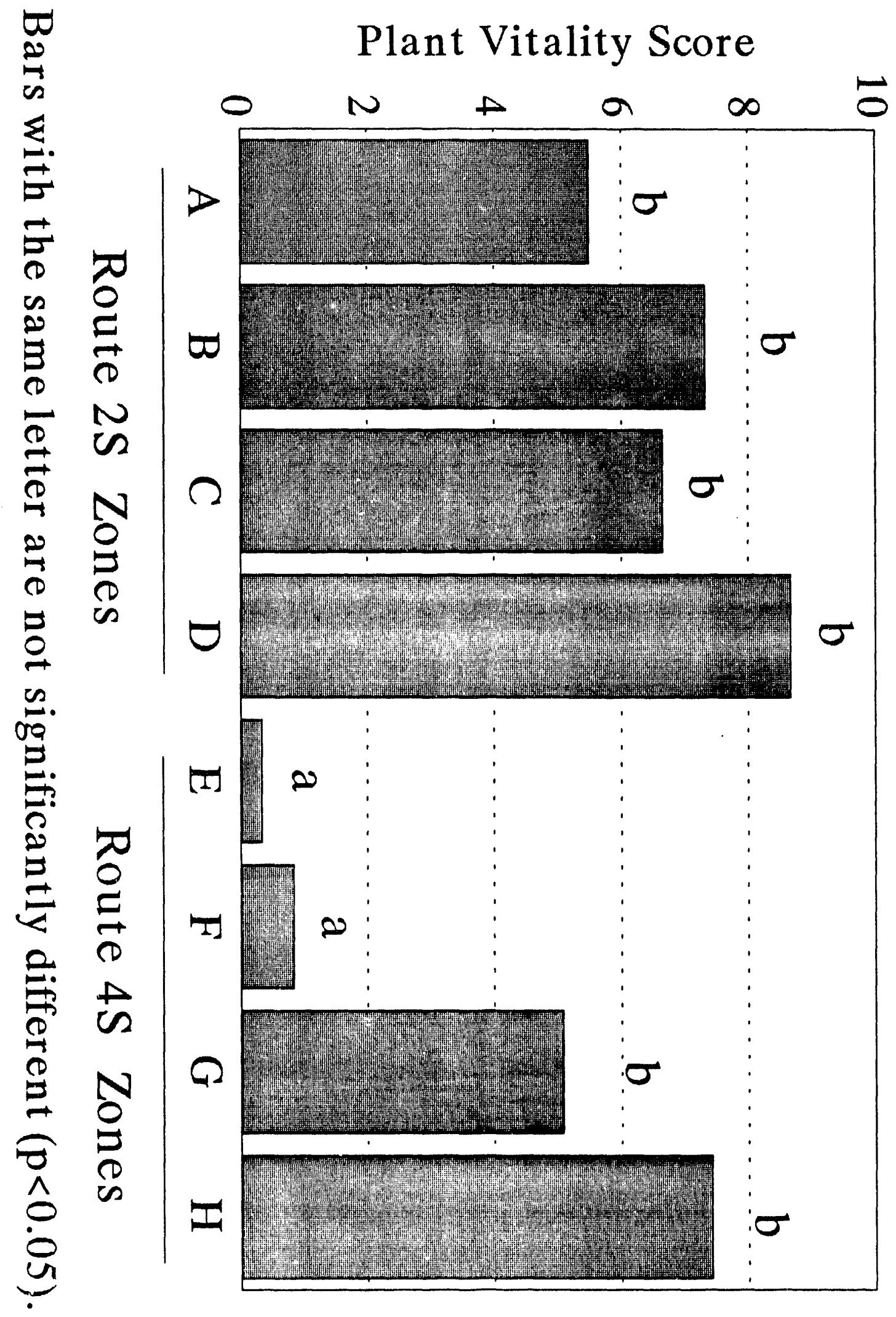

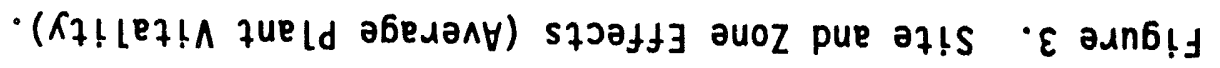




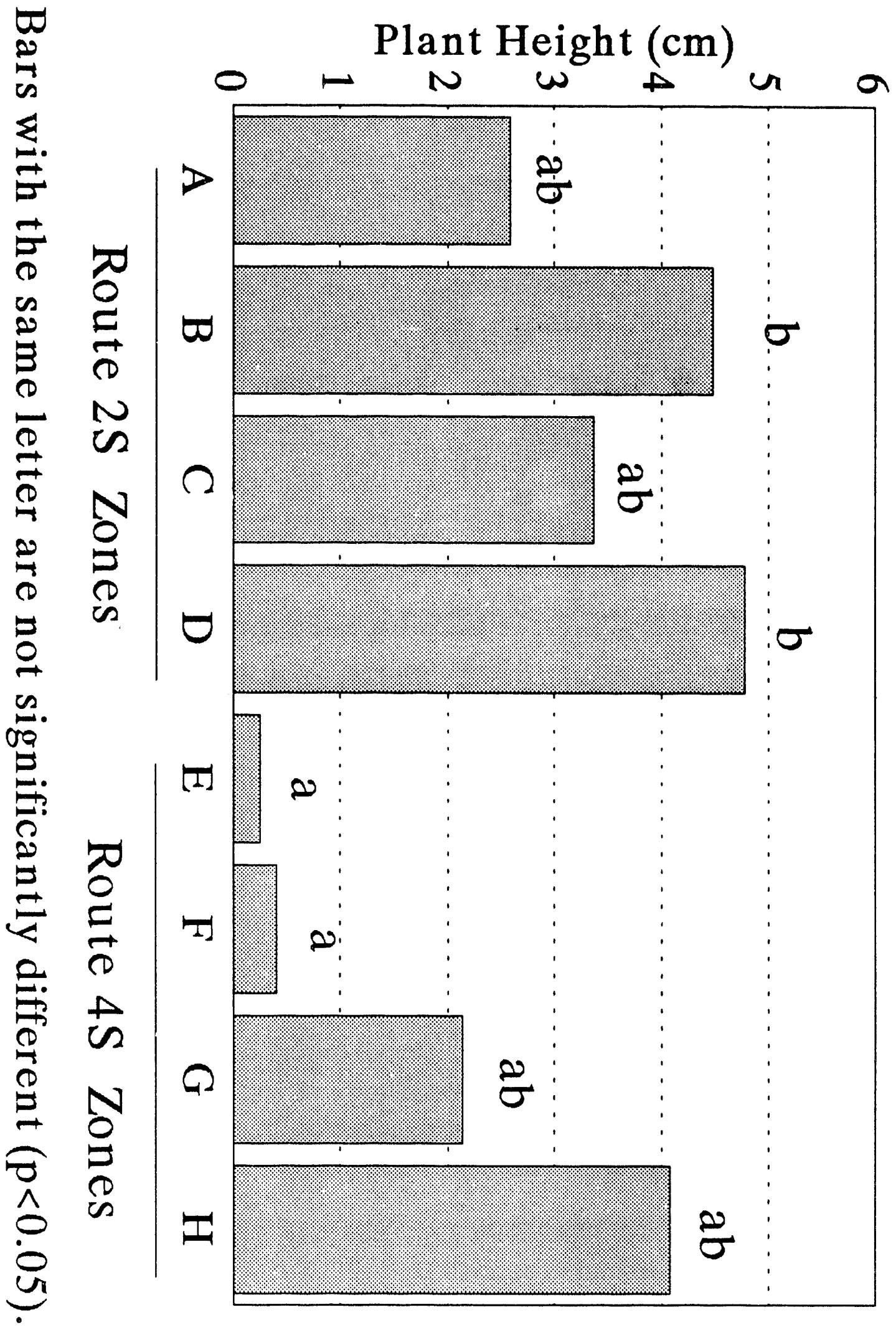

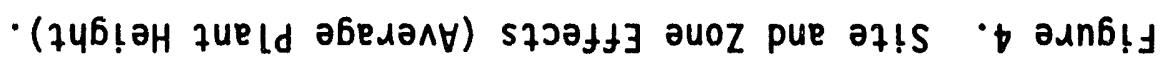


WHC-MR-0426

Figure 5. Site and Zone Effects (Number of Seeds Germinated).

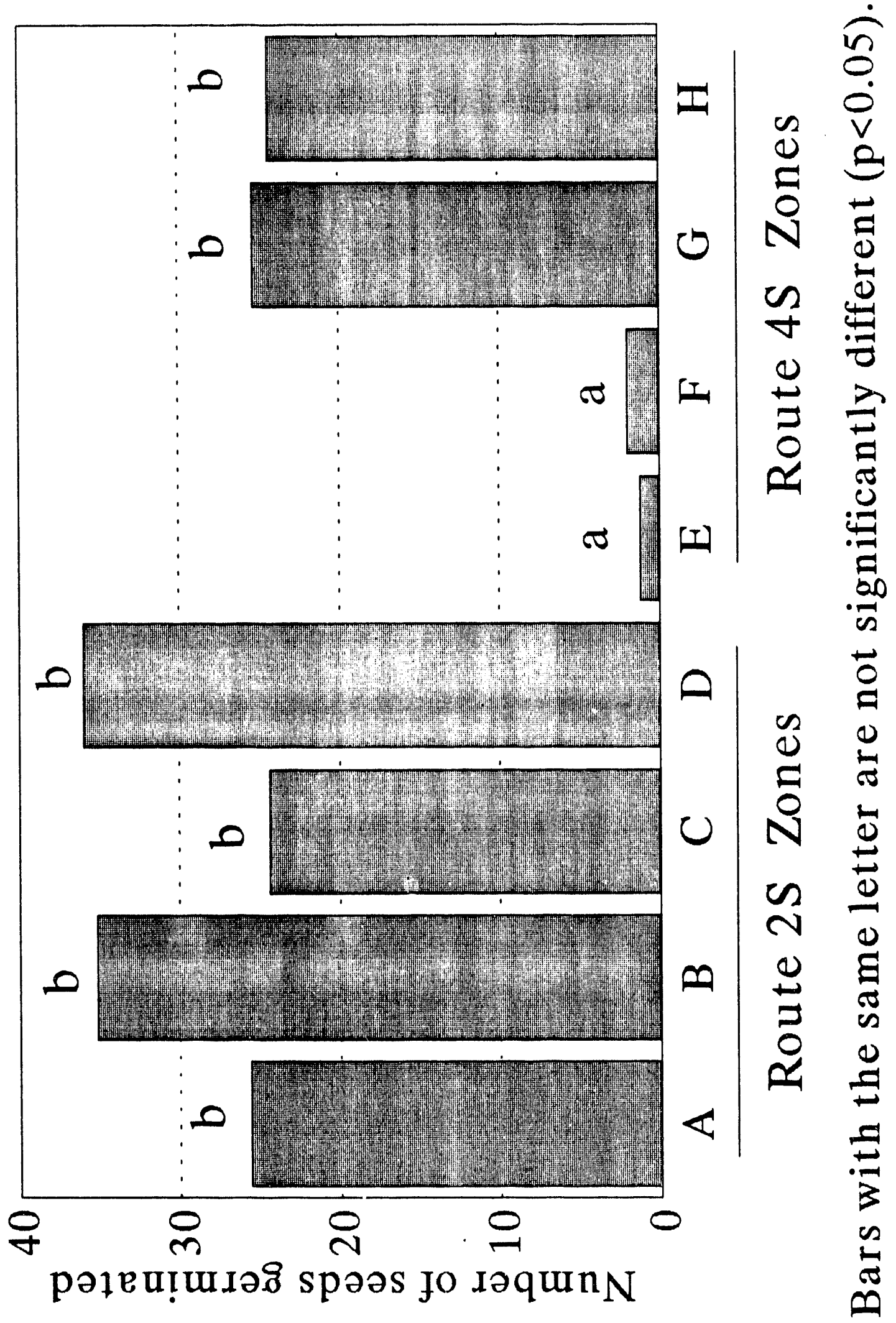


OI

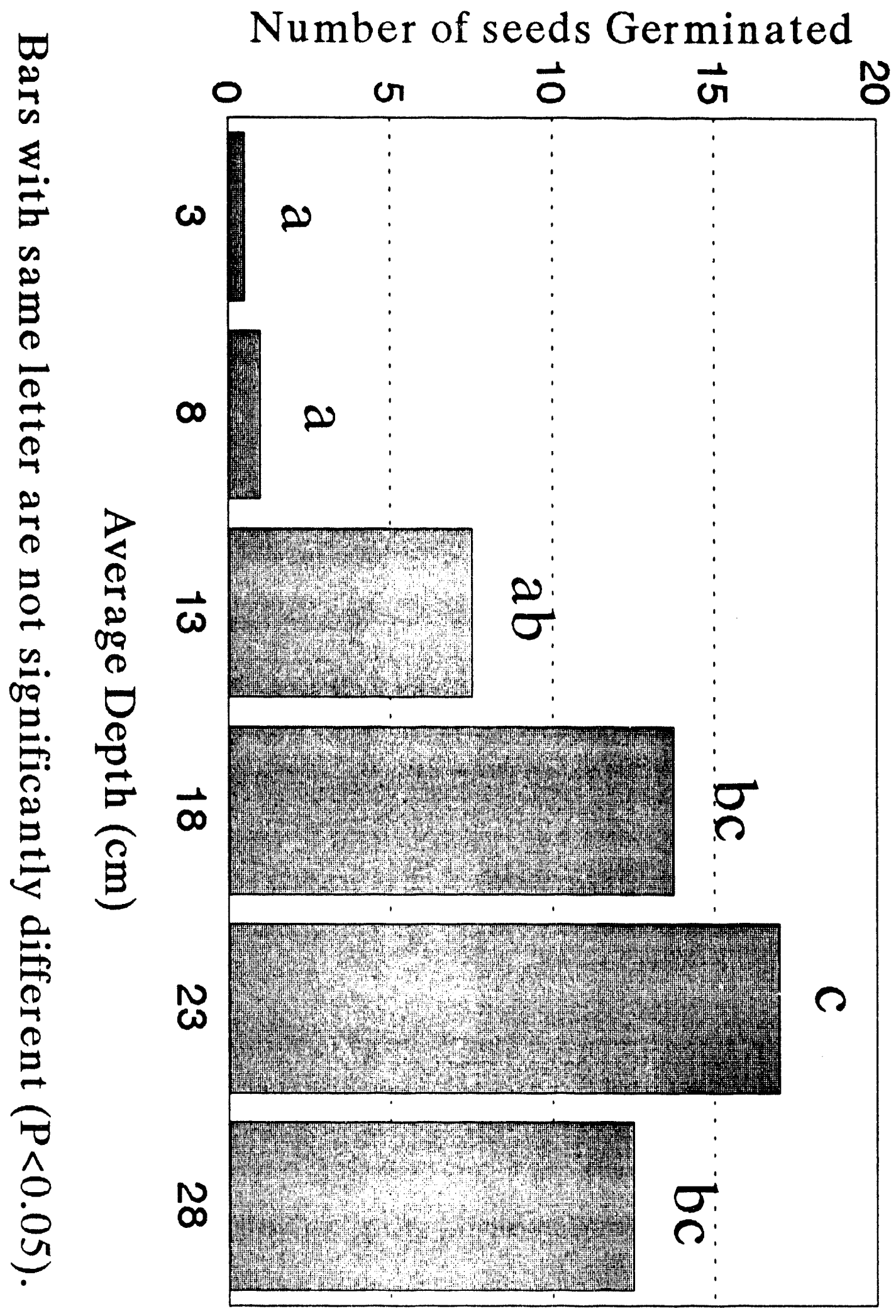

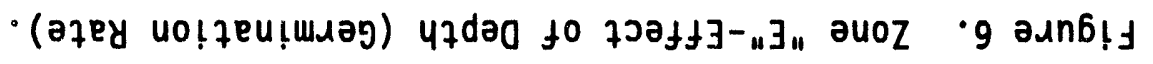




\subsection{SUMMARY AND CONCLUSIONS}

The soils most suitable for germination and sustaining plant growth right up to the road surface were along Route 2 South. Successful revegetation also might be accomplished along Route 4 South at a distance of greater than $20 \mathrm{ft}$ $(6.1 \mathrm{~m})$ from the roadway. The intact soil core showed uniform germination and growth, indicating that there was no residual herbicide activity. The greatest activity was found at depths between 0 and 4 in. $(10.2 \mathrm{~cm})$ belowgrade.

The results of the germination trials provides evidence that revegetation might be successful on Route 2 South. Unfortunately, certain factors diminish the validity of these findings: the experiment provided ideal conditions for germinations and growth and over seeded by a factor of almost 30 . Also, roadsides are typically treated equally 0 to $20 \mathrm{ft}(0$ to $6.1 \mathrm{~m})$ from the roadside; but during roadside maintenance operations, materials are moved from near the roadside and then "feathered" back, so the mixing of treated and untreated soil is an indeterminate variable. So the results of the soil effects may be significant to parts of, but not the total, treated roadsides.

\subsection{REFERENCES}

Hartley, D., and H. Kidd, eds., 1987, The Agrochemicals Handbook, 2nd ed. (England: Royal Society of Chemistry, 1987).

Montgomery, John H., 1993, Agrochemicals Desk Reference, Lewis Publishers. 


\subsection{SUMMARY AND CONCLUSIONS}

The soils most suitable for germination and sustaining plant growth right up to the road surface were along Route 2 South. Successful revegetation also might be accomplished along Route 4 South at a distance of greater than $20 \mathrm{ft}$ $(6.1 \mathrm{~m})$ from the roadway. The intact soil core showed uniform germination and growth, indicating that there was no residual herbicide activity. The greatest activity was found at depths between 0 and $4 \mathrm{in} .(10.2 \mathrm{~cm})$ below grade.

The results of the germination trials provides evidence that revegetation might be successful on Route 2 South. Unfortunately, certain factors diminish the validity of these findings: the experiment provided ideal conditions for germinations and growth and over seeded by a factor of almost 30 . Also, roadsides are typically treated equally 0 to $20 \mathrm{ft}(0$ to $6.1 \mathrm{~m})$ from the roadside; but during roadside maintenance operations, materials are moved from near the roadside and then "feathered" back, so the mixing of treated and untreated soil is an indeterminate variable. So the results of the soil effects may be significant to parts of, but not the total, treated roadsides. 
WHC-MR-0420

\section{REFERENCES}

Hartley, D. and H. Kidd, Eds., 1987, The Agrochemicals Handbook, 2nd ed. (England: Royal Society of Chemistry, 1987).

Montgomery, John H., 1993, Agrochemicals Desk Reference, Lewis Publishers. 
WHC-MR.0426

\section{APPENDIX A}

FINAL TRIAL MEASUREMENTS 
The following table is the final measurement for each trial, the "Vitality" column is a subjective measurement that is included as a guide to the relative vigor of the seedlings (Scale: $0=$ no germination, $10=$ most vigorous).

Table A-1. Trial Measurements. (5 sheets)

\begin{tabular}{|c|c|c|c|}
\hline \multicolumn{4}{|c|}{ Trial 1} \\
\hline & Number of plants & Average height $(\mathrm{cm})$ & Vitality \\
\hline \multicolumn{4}{|c|}{ Zone A } \\
\hline 1 & 34 & 3.5 & 7 \\
\hline 2 & 37 & 3.8 & 7 \\
\hline 3 & 38 & 4.0 & 7 \\
\hline 4 & 34 & 3.3 & 7 \\
\hline \multicolumn{4}{|c|}{ Zone B } \\
\hline 1 & 36 & 4.0 & 7 \\
\hline 2 & 37 & 4.3 & 7 \\
\hline 3 & 33 & 4.5 & 7 \\
\hline 4 & 31 & 4.0 & 7 \\
\hline \multicolumn{4}{|c|}{ Zone C } \\
\hline 1 & 25 & 2.5 & 5 \\
\hline 2 & 33 & 2.5 & 5 \\
\hline 3 & 38 & 2.5 & 5 \\
\hline 4 & 30 & 2.5 & 5 \\
\hline \multicolumn{4}{|c|}{ Zone D } \\
\hline 1 & 32 & 4.5 & 8 \\
\hline 2 & 38 & 4.6 & 8 \\
\hline 3 & 36 & 4.7 & 8 \\
\hline 4 & 36 & 4.6 & 8 \\
\hline \multicolumn{4}{|c|}{ Zone E } \\
\hline 1 & 3 & 0.5 & 1 \\
\hline 2 & 0 & 0.5 & 1 \\
\hline 3 & 6 & 0.5 & 1 \\
\hline 4 & 5 & 0.5 & 1 \\
\hline \multicolumn{4}{|c|}{ Zone $\mathrm{F}$} \\
\hline 1 & 0 & 0 & 0 \\
\hline 2 & 8 & 0.2 & 1 \\
\hline 3 & 1 & 0.1 & 1 \\
\hline 4 & 5 & 0.5 & 1 \\
\hline
\end{tabular}


Table A-1. Trial Measurements. (5 sheets)

\begin{tabular}{|c|c|c|c|}
\hline & Number of plants & Average height $(\mathrm{cm})$ & Vitality \\
\hline \multicolumn{4}{|l|}{ Zone G } \\
\hline 1 & 0 & 0 & 0 \\
\hline 2 & 28 & 3.7 & 3 \\
\hline 3 & 22 & 1.5 & 3 \\
\hline 4 & 25 & 3.5 & 3 \\
\hline \multicolumn{4}{|l|}{ Zone $\mathrm{H}$} \\
\hline 1 & 35 & 3.5 & 7 \\
\hline 2 & 36 & 3.5 & 7 \\
\hline 3 & 29 & 3.5 & 7 \\
\hline 4 & 31 & 3.5 & 7 \\
\hline \multicolumn{4}{|c|}{ Trial 2} \\
\hline \multicolumn{4}{|l|}{ Zone A } \\
\hline 1 & 0 & 0 & 0 \\
\hline 2 & 18 & 1.5 & 6 \\
\hline 3 & 26 & 2.0 & 6 \\
\hline 4 & 32 & 2.0 & 6 \\
\hline \multicolumn{4}{|l|}{ Zone B } \\
\hline 1 & 19 & 1.5 & 7 \\
\hline 2 & 57 & 2.0 & 7 \\
\hline 3 & 36 & 2.5 & 7 \\
\hline 4 & 32 & 1.5 & 7 \\
\hline \multicolumn{4}{|c|}{ Zone C } \\
\hline 1 & 16 & 1.0 & 7 \\
\hline 2 & 22 & 1.5 & 7 \\
\hline 3 & 19 & 1.0 & 7 \\
\hline 4 & 34 & 2.0 & 7 \\
\hline \multicolumn{4}{|c|}{ Zone D } \\
\hline 1 & 42 & 2.5 & 9 \\
\hline 2 & 36 & 2.5 & 9 \\
\hline 3 & 37 & 2.0 & 9 \\
\hline 4 & 50 & 2.0 & 9 \\
\hline \multicolumn{4}{|c|}{ Zone E } \\
\hline 1 & 0 & 0 & 0 \\
\hline 2 & 0 & 0 & 0 \\
\hline
\end{tabular}


Table A-1. Trial Measurements. (5 sheets)

\begin{tabular}{|c|c|c|c|}
\hline & Number of plants & Average height $(\mathrm{cm})$ & Vitality \\
\hline 3 & 0 & 0 & 0 \\
\hline 4 & 1 & 1.5 & 1 \\
\hline \multicolumn{4}{|l|}{ Zone $\mathrm{F}$} \\
\hline 1 & 0 & 0 & 0 \\
\hline 2 & 0 & 0 & 0 \\
\hline 3 & 0 & 0 & 0 \\
\hline 4 & 9 & 1.0 & 1 \\
\hline \multicolumn{4}{|c|}{ Zone G } \\
\hline 1 & 38 & 2.0 & \\
\hline 2 & 39 & 2.5 & 8 \\
\hline 3 & 6 & 0.5 & 4 \\
\hline 4 & 29 & 2.0 & 8 \\
\hline \multicolumn{4}{|c|}{ Zone $\mathrm{H}$} \\
\hline 1 & 33 & 2.5 & 9 \\
\hline 2 & 36 & 3.0 & 9 \\
\hline 3 & 0 & 0 & 0 \\
\hline 4 & 16 & 1.5 & 0 \\
\hline \multicolumn{4}{|c|}{ Trial 3} \\
\hline \multicolumn{4}{|c|}{ Zone A } \\
\hline 1 & 36 & 3.0 & 5 \\
\hline 2 & 12 & 2.0 & 5 \\
\hline 3 & 39 & 4.0 & 5 \\
\hline 4 & 1 & 2.0 & 5 \\
\hline \multicolumn{4}{|c|}{ Zone B } \\
\hline 1 & 45 & 8.0 & 8 \\
\hline 2 & 28 & 7.0 & 8 \\
\hline 3 & 32 & 5.5 & 8 \\
\hline 4 & 36 & 9.0 & 8 \\
\hline \multicolumn{4}{|c|}{ Zone C } \\
\hline 1 & 17 & 5.0 & 8 \\
\hline 2 & 19 & 7.5 & 8 \\
\hline 3 & 12 & 4.5 & 8 \\
\hline 4 & 28 & 8.0 & 8 \\
\hline
\end{tabular}


Table A-1. Trial Measurements. (5 sheets)

\begin{tabular}{|c|c|c|c|}
\hline & Number of plants & Average height $(\mathrm{cm})$ & Vitality \\
\hline \multicolumn{4}{|c|}{ Zone D } \\
\hline 1 & 33 & 8.5 & 9 \\
\hline 2 & 38 & 7.0 & 9 \\
\hline 3 & 32 & 8.5 & 9 \\
\hline 4 & 22 & 6.0 & 9 \\
\hline \multicolumn{4}{|c|}{ Zone $\mathrm{E}$} \\
\hline 1 & 0 & 0 & 0 \\
\hline 2 & 0 & 0 & 0 \\
\hline 3 & 0 & 0 & 0 \\
\hline 4 & 0 & 0 & 0 \\
\hline \multicolumn{4}{|c|}{ Zone F } \\
\hline 1 & 2 & 1.0 & 2 \\
\hline 2 & 3 & 1.0 & 2 \\
\hline 3 & 0 & 0 & 2 \\
\hline 4 & 4 & 0.5 & 2 \\
\hline \multicolumn{4}{|c|}{ Zone $G$} \\
\hline 1 & 52 & 5.0 & 8 \\
\hline 2 & 48 & 2.0 & 8 \\
\hline 3 & 5 & 1.0 & 3 \\
\hline 4 & 12 & 2.0 & 5 \\
\hline \multicolumn{4}{|c|}{ Zone $\mathrm{H}$} \\
\hline 1 & 22 & 6.0 & 9 \\
\hline 2 & 15 & 6.5 & 9 \\
\hline 3 & 18 & 7.0 & 9 \\
\hline 4 & 22 & 8.5 & 9 \\
\hline \multicolumn{4}{|c|}{ Trial 4} \\
\hline \multicolumn{4}{|c|}{0 to 2 in. } \\
\hline \multicolumn{4}{|c|}{ Zone $\mathrm{E}-1$} \\
\hline 1 & 0 & 0 & 0 \\
\hline 2 & 0 & 0 & 0 \\
\hline 3 & 2 & 2.5 & 2 \\
\hline 4 & 0 & 0 & 0 \\
\hline
\end{tabular}


Table A-1. Trial Measurements. (5 sheets) \begin{tabular}{l|l|l|l} 
Number of plants & Average height $(\mathrm{cm})$ & Vitality \\
\hline
\end{tabular} 2 to 4 in.

Zone E-2

\begin{tabular}{|l|l|l|l|}
\hline 1 & 1 & 1.5 & 2 \\
\hline 2 & 3 & 1.0 & 2 \\
\hline 3 & 0 & 0 & 0 \\
\hline 4 & 0 & 0 & 0 \\
\hline \multicolumn{2}{|r|}{4 to 6 in. } \\
\hline
\end{tabular}

\section{Zone E-3}

\begin{tabular}{|c|c|c|c|}
\hline 1 & 0 & 0 & 0 \\
\hline 2 & 10 & 3.0 & 4 \\
\hline 3 & 8 & 4.0 & 4 \\
\hline 4 & 12 & 2.0 & 4 \\
\hline \multicolumn{3}{|c|}{6 to 8 in. } \\
\hline
\end{tabular}

Zone E-4

\begin{tabular}{|l|l|l|l|}
\hline 1 & 18 & 5.0 & 4 \\
\hline 2 & 13 & 6.5 & 4 \\
\hline 3 & 14 & 4.5 & 4 \\
\hline 4 & 10 & 3.0 & 4 \\
\hline \multicolumn{3}{|c|}{8 to 10 in. } \\
\hline
\end{tabular}

Zone E-5

\begin{tabular}{|l|c|c|c|}
\hline 1 & 8 & 3.5 & 4 \\
\hline 2 & 15 & 5.5 & 4 \\
\hline 3 & 24 & 7.0 & 5 \\
\hline 4 & 21 & 6.5 & 5 \\
\hline \multicolumn{2}{|c|}{10 to 12 in. } \\
\hline
\end{tabular}

Zor:e E-6

\begin{tabular}{|l|c|c|c|}
\hline 1 & 5 & 7.0 & 5 \\
\hline 2 & 10 & 3.0 & 3 \\
\hline 3 & 12 & 4.0 & 4 \\
\hline 4 & 17 & 5.5 & 5 \\
\hline
\end{tabular}




\section{DISTRIBUTION}

\begin{tabular}{clc} 
Onsite & & \\
\hline 20 & D.W. Brown & N3-06 \\
& J.W. Cammann & H4-14 \\
M.J. Elsen & A7-27 \\
B.J. Hobbs & N3-06 \\
C.J. Kemp & $H 4-14$ \\
R.R. Knight & G4-07 \\
D.S. Landeen & H4-14 \\
C.L. Looney & N3-06 \\
M.B. Malady & N3-06 \\
M.R. Sackschewsky & $H 4-14$ \\
D.L. Smith & R2-77 \\
J.L. Smith (5) & H4-14 \\
J.C. Sonnichsen & $H 4-14$ \\
Information Release & $H 4-17$ \\
Central Files & L8-04 \\
DOE-RL Reading Room & L8-15
\end{tabular}



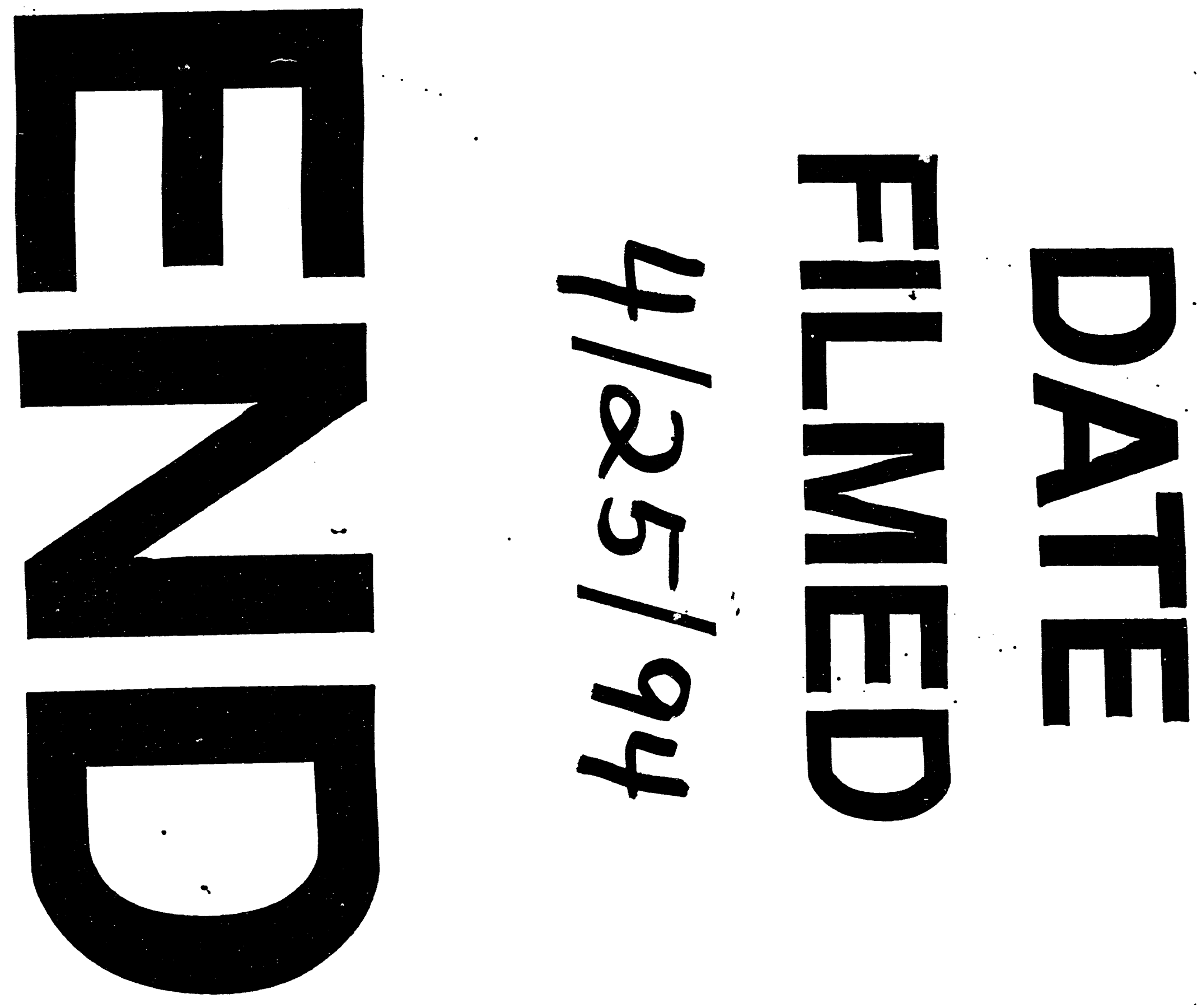
